\title{
«что делает двявол на нашем диване?»: Холокост и Ленинградская блокада в прозе Сильвии Хутник, Игоря Остаховича, Андрея Тургенева
}

В циркуляцию пост-памяти о травме включены и те, кто не связан с исторической травмой непосредственно, «генетически» ${ }^{1}$. Д. Лакапра называет травму «заразной» - она распространяется даже не только через непосредственное общение со свидетелями, но и посредством научной, художественной рефлексии, СМИ, включается в процесс самоидентификации как проекция² .

Әто опыт, например, десятилетиями вытеснявшейся травмы, связанной с (со) участием поляков в Холокосте. Опыт стыда вообще «с трудом включается в багаж памяти, поскольку не создает позитивного образа себя или социума» ${ }^{3}:$ любое национальное государство «тщательно конструирует общее историческое наследие и делает все возможное, чтобы дискредитировать или подавить память

1 Szczepan A. Polski dyskurs posttraumatyczny. Literatura polska ostatnich lat wobec Holokaustu i tożsamości żydowskiej // Kultura po przejściach, osoby z przeszłością. Kraków: Universitas, 20II. S. 243.

2 LaCapra D. Historia w okresie przejściowym. Doświadczenie, tożsamość, teoria krytyczna. Kraków: Universitas, 2009. S. 108.

3 Assmann A. Między historią a pamięcią. Antologia. Warszawa: Wydawnictwo Uniwersytetu Warszawskiego, 2013. S. 5I.

\footnotetext{
* Irina Adelgejm - polonistka, pracownik Instytutu Słowianoznawstwa Rosyjskiej Akademii Nauk. Autorka monografii i artykułów o literaturze polskiej, przede wszystkim o prozie XX i XX wieku (Польская проза межвоенного двадиатилетия:между Западом и Россией. Феномен психологическогоязика, гооо; Поэтика „промежутка”: молодая польская проза после г989 года, 2005; Психология поэтики. Аутопсихотерапевтические функции художественного текста, 2ог8). Tłumaczka Gustawa Herlinga-Grudzińskiego, Olgi Tokarczuk, Pawła Huellego, Mariusza Wilka, Andrzeja Stasiuka, Ewy Kuryluk, Małgdaleny Tulli, Filipa Bajona, Krzysztofa Kieślowskiego, Tadeusza Różewicza, Krystyny Jandy, Manueli Gretkowskiej i in.
} 
о событиях, нарушающих декларируемую общность национальной традиции» ${ }^{4}$. Поэтому такого рода опыт долго не находит символического выражения. Именно здесь - в обновлении коллективной памяти, особенно когда речь идет о проработке постыдных воспоминаний ${ }^{5},-$ важнейшую роль играет смена поколений. Чувство стыда и страха, потребность прервать «культуру молчания» ${ }^{6}$, сознательно проработать прошлое ощущается в мировосприятии Игоря Остаховича и Сильвии Хутник.

Применительно к Андрею Тургеневу (псевдоним Вячеслава Курицына) и не только (современная русская литература 20оо-2ого-х гг. сосредоточивает внимание на теме блокады Ленинграда, причем место текстов, посвященных блокаде, ощущается и понимается литературным сообществом (а в ряде случаев и «общественностью» в целом) как системно важное $)$ - это попытка освободиться от смыслов, навязанных советским победным большим нарративом, и найти свой язык для повествования о Ленинградской блокаде. Победа в Великой Отечественной войне остается в коллективном сознании единственным моментом в прошлом, ценность которого не была девальвирована в постсоветский период и потому оказывается единым ценностным ориентиром для оценки настоящего и «точкой сборки» коллективной идентичности постсоветского человека.

Здесь мы также имеем дело - хотя и иным в смысле отношений субъекта/ объекта, палача/жертвы/свидетеля - с негибкостью, ригидностью позитивного самоотождествления с героическим прошлым, что одновременно провоцирует выход за рамки присущих этому сознанию стереотипов.

И блокада Ленинграда оказывается событием, «предельно проблематизирующим самые неудобные вопросы, связанные как раз с ценой войны и с теми жертвами, которые, в формулировке официальной позднесоветской риторики, были «принесены на алтарь Победы» ${ }^{8}$. Мемориализация блокады была направлена на установление причинно-следственной связи между массовой гибелью людей и героической мартирологией (потому и началась далеко не сразу). В коллективной памяти сформировался своего рода «блокадный миф», оправдывающий массовую гибель людей как «добровольную» и «героическую» жертву - сработал своего рода защитный механизм.

4 Bauman $Z$. Wieloznaczność nowoczesna, nowoczesność wieloznaczna. Warszawa: Wydawnictwo Naukowe PWN, 1995. S. 94.

5 Ассман А. Длинная тень прошлого. Мемориальная культура и историческая политика. Москва: НЛО, 2014. С. 16.

6 Tokarska-Bakir J. Historia jako fetysz // Tokarska-Bakir J. Rzeczy mgliste. Sejny: Pogranicze, 2004. S. 98 .

7 Воробьева (Вежлян) Е. Прорвать заграждение: блокада Ленинграда как символ и опыт // НЛО. 2016. №ı URL: https://www.nlobooks.ru/magazines/novoe_literaturnoe_obozrenie/137_nlo_I_2016/ article/II8ог/ Дата обращения: ог.о2.202I

8 Ibid. 
Роман И. Остаховича «Ночь живых евреев» (2012) и рассказ Сильвии Хутник «Муранооо» (20I4) - яркое воплощение ощущения как личной травмы «запятнанности» Польши сотворенным на ее территории, на глазах у поляков и при их участии Злом.

Варшава описывается молодыми авторами как город, стоящий в буквальном смысле на трупах, на крови, на костях. Здесь после войны на руинах и из руин (действительно зачастую вперемешку с костями - из производившегося прямо на месте пустотелого кирпича типа «Муранов») сожженного гетто был выстроен социалистический район-утопия Муранов, представлявший собой воплощенное забвение - на протяжении десятилетий ничто в нем не напоминало о бывших обитателях. Еврейский слой варшавского «палимпсеста» был стерт, территория осваивалась как чистый лист. Характерно, что местом действия значительной части романа Остаховича является ТЦ «Аркадия», пространство, представляющее собой наглядное столкновение двух миров - иллюзии вечного счастья потребительства и вытесненной на потребу глянцевому благополучию памяти о Холокосте (торговый центр выстроен на месте депо, из которого шли әшелоны в концлагерь).

Еврейское прошлое города воспринимается авторами как непосредственно соприкасающееся с сегодняшней мирной жизнью подполье. И эта проза действительно исследует локус подвала - как пространства, связанного с инфернальной областью, пространства смерти. Спуск туда живых и выход оттуда мертвых ассоциируется с нарушением границы между жизнью и смертью, с погребением заживо, посмертным блужданием неупокоенной души и одновременно с глубинами памяти (из дыры в подвале доносится «шум, как из раковины, если ее приложить к уху ${ }^{9}$ : в раковине, как мы знаем, шумит не море, а наша собственная кровь - так и здесь шумят не мертвые, а память живых).

Район Муранов, по сути, воплощает топос «проклятого дома», населенного призраками. Одновременно он осмысляется и как своего рода огромный «подвал» Польши, вытесняемое в подсознание болезненное прошлое: «Знаете, это такой кусочек засохший на карте. Струп на карте, не желающий отваливаться, крепко держащийся. Мы его сдираем, под ним блестит сукровица и выплескивается при каждом движении»; «Да, кто-то шепчет, кто-то нам тайные знаки подает из самого темного угла, из развалин дома»; неслучайно спустившиеся в подвал польские дети чувствовали, «как их постепенно засасывает эта подвальная история, скользкая повесть, блуждающая вдоль стен и шепчущая все громче: "Муранооо"»10.

«Возвращение» души-призрака всегда аномально и свидетельствует о некоей нерешенной вовремя проблеме. В данном случае - это не пережитый варшавянами траур по еврейским соседям (что, по определению Р. Сендыки, является общей

9 Chutnik S. W krainie czarów. Kraków: Znak, 20I4. S. 54.

10 Ibid. S. I22, I35. 
чертой «не-мест памяти» $\left.{ }^{11}\right),-$ неслучайно 3. Бауман называет мир после Холокоста «полным призраков» ${ }^{12}$. Жертвы Холокоста противопоставлены польским жертвам оккупации, многократно оплаканным, т.е. возникает образ вытеснения из памяти чужих страданий в пользу польской национальной мартирологии.

Чувство стыда сублимируется в мотивы страха и возмездия - умершие напоминают о себе - шепчут, шумят, угрожают, умоляют, убаюкивают, будят и т.д.: «Му-ра-нооо. Как какое-то угрызение совести или заклятие, которое невозможно расшифровать. До утра клубилось между ушами, взывало, шумело, сеяло беспокойство»; «что это за жизнь - когда вынужден постоянно вынюхивать заговор призраков»; «В этом городе невозможно заснуть, душно-беспокойно. В ушах свистит чей-то шепот, кто-то приближает свои дрожащие губы и тихонько напевает: „Муранооо, Муранооо“»; «Представь себе, что ты в таком доме должен жить, а дом не твой, он принадлежит этим мертвецам»; «Они здесь, снились бабушке в эту ночь, нашептывали ей на ухо странные предсказания. Закопай нас, просили они, убей нас, умоляли, тогда мы не убьем тебя, обещали»; «духи, которые якобы во сне трясут ее за плечо и шепчут хрипло на ухо: Муранооо, помнишь меня, Муранооо»; «Евреи сидят на своих пожитках и стерегут их, вдруг они нам что-нибудь сделают, вдруг нас живьем закопают, помогите. Евреи, словно драконы, покрытые чешуей, хрипло дышат и машут хвостами. А заклятие вы знаете? Блин, не знаем мы никакого заклятия» ${ }^{13}$; «я представил себе, как по всей стране они начинают вылезать из придорожных канав, из-под железнодорожных насыпей и отправляются в близлежащие городки - рассказать о своих страданиях и чайку попить [...]. Боюсь, что живые к этому не готовы» ${ }^{14}$.

Рассказ Хутник «Муранооо» представляет собой помесь сказки в духе братьев Гримм и детской «страшилки» с ее абсурдом, развернутый эпизод черного юмора, совмещающий в себе элементы комического и ужасного. В рассказе причудливо сочетаются «гриммовская» простота и жестокость логики с доведенными до абсурда, но узнаваемыми польскими стереотипами («Потому что евреи ленились. Им попросту не хотелось убегать. Поляки то и дело высовывались из-за забора и кричали им: “Эй!” А те: “Да ладно”. Тогда поляки снова: “Эй! Мы вам ковер-самолет дадим, сядете на него да и улетите из этого гетто”. Из-за стены в ответ, что, мол, ковры грязные. Тогда польская армия - давай пылесосы сбрасывать. Без мешков! Энергосберегающие пылесосы в гетто кидали, чтобы эти неженки задницы себе не запачкали. А они - ноль реакции, передумали, мол. Капризничают: “Не-ет. Нам неохота. Нам и тут хорошо, в нашем маленьком городе Муранооо” [...]. Вот и говори с ними после этого. Объясняешь, помогаешь - а они свое. Только головами мотают да ногой притоптывают»; «Самое

11 Sendyka R. Pryzma. Zrozumieć nie-miejsce pamięci // Teksty Drugie. 2013. № I /2.

12 Bauman $Z$. Świat nawiedzony // Więź. 2007. № 9.

13 Chutnik S. W krainie czarów. S. 133, I20, I21, I24, I32, 133, I35-136.

14 Ostachowicz I. Noc żywych Żydów. Warszawa: WAB, 2012. S. 184. 
главное, что на территории этого города, которого уже нет, теперь есть сокровища. Многие люди свои стеклянные глаза, золотые зубы, кольца и цепочки закопали. Я столько раз говорила, чтобы вы вниз спустились и яму выкопали»; «А внизу сидят духи и сокровища сторожат» ${ }^{15}$ ). Стыд маскируется гротеском, страх - черным юмором, однако проблема присутствующего в коллективном подсознании чувства вины так и не решена: «Все варшавские призраки закопались еще глубже и ждут-пождут» ${ }^{16}$.

Неожиданное появление жертв Холокоста на пороге квартиры современного «чистокровного поляка» у Остаховича также воплощает страх перед вытесненным, неоплаканным еврейским прошлым Варшавы и, шире, Польши. Здесь можно увидеть прямую аллюзию на «Бесславных ублюдков» (2009) К. Тарантино и идею «справедливого Холокоста» ${ }^{17}$, т.е. мести: «Они видели, как посылали тех, кого они когда-то любили, так что теперь хотят увидеть, как туда пойдут те, кого они не любят» ${ }^{18}$.

Роман основан на игре с поп-культурой, отсылает к әстетике комикса, компьютерных игр, триллеру, представляет собой гротескное смешение кодов, жанров, цитат. Так, здесь есть характерный эвримен, из обывателя волею судьбы превращающийся в благородного супермена, есть враги, наставник, верная подруга, дающий силу случайно попавший в руки героя артефакт и борьба за него, антагонист (антисемит, превращающийся в дьявола), кульминационное событие - заглавная Ночь живых евреев, в которую благородному герою ценой собственной жизни удается достичь цели.

Остахович применяет карнавальное освоение табуированной темы - вытесняемого зла, присутствующего в польском прошлом: «Что делает дьявол на нашем диване? [...] Мы стоим, обнявшись, смотрим на краснокожее, рогатое существо, которое уже ничем не притворяется, а просто имеет откровенно жуткий вид. Как случилось, что в нашем доме присутствует столь мерзкое зло? - спрашиваем мы себя» ${ }^{19}$. В романе все реально и наглядно - и зло (живой дьявол в обычном польском доме), и вытесненное из коллективной памяти, неоплаканное прошлое (еврейские трупы-призраки в подвале польского дома, на пороге и на улицах), и маниакальный страх перед этим прошлым (борьба варшавян с трупами). Миссия же героя, спасение еврейских трупов в заглавную Ночь, символизирует необходимость противостоять забвению, вытеснению постыдных фрагментов польского прошлого, необходимость солидарности с теми, кого некому оплакать.

15 Chutnik S. W krainie czarów. S. 123, I28-I29.

16 Ibid. S. I40.

17 Hoberman J. Quentin Tarantino's Inglourious Basterds Makes Holocaust Revisionism Fun // Village Voice. 2009, August I8. www.villagevoice.com/film/quentin-tarantinos-inglourious-basterds-makesholocaust-revisionism -fun-6391999

18 Ostachowicz I. Noc żywych Żydów. S. 63, 88.

19 Ibid. S. 135 . 
Не менее провокационен текст одного из главных теоретиков и критиков отечественного постмодернизма Вячеслава Курицына «Спать и верить» (2007), имеющий подзаголовок «блокадный роман».

В силу возраста также имея возможность работать с травматическим опытом только с позиции пост-памяти, писатель в значительной степени опирается на два текстовых материала разной степени опосредованности - свидетельство и главный текст советского «победного нарратива»- эпопею А. Чаковского «Блокада» (1968-1975).

Он привлекает большой массив документов и свидетельств, фрагменты некоторых включены в текст романа в виде скрытых цитат, а в целом они в значительной степени составляют плоть изображаемой реальности, в том числе эмоциональной, блокадного города (ср., например: «Прошлым летом он просыпался иначе - всегда в шесть утра, от звука репродуктора, для общего пользования установленного в коридоре. Потом, уже по привычке, он стал просыпаться за десять-пятнадцать минут и лежал, прислушиваясь. Минуты за три, не утерпев, он в пижаме выходил в коридор. Там стояли уже соседи, полуодетые, с жадно-напряженными лицами» ${ }^{20}$ и «В начале войны было по-другому. Генриетта Давыдовна сама просыпалась за четверть часа до шестичасового писка черной тарелки. Ждала-ожидала, прислушивалась. За минуту-другую Александр Павлович не вытерпливал, снарядившись кое-как выскакивал в коридор...» ${ }^{21}$ и др.).

В романе можно выделить три пласта.

Во-первых, это реконструкция объективной реальности блокадного города, а также советского сознания его жителей (с серьезной поправкой на то, о чем мы знаем сегодня - антисоветские и пронемецкие настроения, людоедство) основанное на свидетельствах и документах воспроизведение реалий, типажей, моделей ситуаций, поведения, чувствования. Это, условно говоря, «простые ленинградцы» в пограничной ситуации и одновременно проекции бытующих в массовом сознании представлений о ленинградском блокадном прошлом.

Вторая группа героев и второй пласт действительности, в описании которых преобладает карикатурно-шаржированный образно-мотивный ряд постмодерна, - партийная верхушка. Портрет «хозяина города» Марата Кирова, обстановка его кабинета, застолья, окружение написаны с элементами сатирической, раблезианской, гоголевской, сорокинской гиперболизации. «Марат Киров, хозяин Ленинграда, могучий секретарь обкома, сидел за огромным - чуть меньше Марсова поля - столом в своем домашнем кабинете на Петроградской стороне»; «Арбузов оказался квадратным. Роста маленького, а ширины плеч чрезвычайной, ровно как раз в рост. Голова такая же, то есть еще лучше - просто кубом, и прическа ежиком с прямыми углами. Посреди лица подкрученные эдак так

20 Гинзбург Л. Записки блокадного человека. Избранная проза. Санкт-Петербург: Лениздат, 20I4. C. 266.

21 Тургенев Андрей. Спать и верить: Блокадный роман. M., 2007. URL: https://royallib.com/read/ turgenev_andrey/spat_i_veritblokadniy_roman.html\#о Дата обращения: оI.02.202I. 
по-кавказски, похожие на знак интеграла черные усы. Вместе с большим и кругло-рыхлым Здренко, который тоже находился здесь, они походили на методический материал к безумному геометрическому учению»; «Рацкевич набрался сверх всяких зюзь, сшибал столы и сотрудников, палил в окно»; «Икра, масло, осетрина, овощи без приправ, соленья, язык, хлеб, хрен. Марат Киров уважал простую пищу, без наворотов. Без всех этих глупостей!»; «Әтот соблазн Киров в себе придушил, зато ударился в обжорство. [...] Забросать зияющую пропасть котлетами, засыпать туманные рвы салатами, залить пустоту коньяком. Припоршить черную беспроглядную неизвестность згами жареной картошки и соленых грибов. А то, что вокруг, в радиусе пусть не вытянутой руки, но пистолетного выстрела тысячи земляков умирали от голода, придавало жратве пикантную мифологичность, остроту ритуального танца на самом краешке света, земного диска, человечьего бытия. Ел, как убивал, как палач казнит, кровавые брызги летели. Урчал, рыгал, перемалывал мощными челюстями мозговые кости. Соратники в Смольном этаж его обходили, когда ел, дома жена с кухаркой прятались, как мыши, на черной лестнице» ${ }^{22}$.

Наконец, третий пласт - плоскость уже откровенного абсурда, бреда, фантасмагории, связанная с образом Максима, полковника НКВД, который командирован в Ленинград из Москвы. Он - связующее звено между блокадниками и властью, легко перемещается из коммунальных квартир и вымирающих улиц в закрытые кабинеты Большого дома, помощник и убийца, спаситель и провокатор, одновременно (соц)реалистичен как образ полковника и таинственно-мистичен как образ «Джокера», «Четырехпалого», бросающего в Неву бутылки с письмами Гитлеру (здесь можно увидеть аллюзию на героя романа Аксенова «Москва ква-ква» Моккинаки, тайного шпиона). И если образы «простых ленинградцев» преимущественно окрашены в положительные тона, а «верхушка», вся без исключения, изображается как сборище нравственных уродов и убийц, обжор и похотливых подонков, то Максим противоречив и загадочен даже для себя самого (неслучайно в письмах к Гитлеру он то настаивает на уничтожении города, то просит о его сохранении).

Во второй половине романа бред, гротеск нарастают, как снежный ком. Просьбы Гитлеру странным образом сбываются «Максим торжествовал. Последняя бутылка достигла цели: и про радий послушался фюрер, и про карточки» ${ }^{23}$. Максим носится с идеей поставить в декорациях блокадного города якобы принадлежащую Вагнеру оперу «Вечный лед» (пародийно-безумное либретто которой включено в текст). Вместе с разочаровавшимися в советской действительности мальчиком и бывшей спортсменкой-альпинисткой, а также духом-глоссолалом, Максим замышляет и осуществляет не удавшееся покушение на Марата Кирова, до поры до времени ловко избегает подозрений со стороны ленинградских нквдшников, хулиганит, безумствует («Вспоминал про

22 Ibid.

23 Ibid. 
карточки-радий, хохотал, как ловко он все уделал, руками махал, подпрыгивал, да еще и в форме вышел в тот день, кобура болтается, встречные не знали куда и шарахнуться. Так надо призраков, призраков пускать по городу, чего Викентий Порфирьевич сидит-простаивает, нарядить с черепом-смертью - и на улицы: шарахать, пугать!» ${ }^{24}$ и т.д.

Прецедентный текст Чаковского с его «непротиворечивой гладкой картинкой, однородной и в обобщениях, и в частностях, независимо от масштаба рассмотрения» ${ }^{25}$ Тургенев использует для деконструкции советского блокадного мифа, разнообразно соотнося ряд своих персонажей с героями эпопеи - типичными представителями советских ленинградцев.

Текст Чаковского, как и свидетельства, иногда используется Тургеневым как материал для лепки плоти романа, однако с сознанием автором художественно-идеологической опосредованности этого материала (например, он вводится в виде фотографии), но прежде всего - пародийно остраняется.

Так, сознание главной героини Тургенева Вари соотносится с представлениями идеальной комсомолки Веры Чаковского - в том числе, очень последовательно, в моментах, связанных с эмоционально-чувственной жизнью, а любовный треугольник в «Спать и верить» восходит к треугольнику романа «Блокада». Варя-Вера должна сделать выбор между женихом, ушедшим на фронт, и кадровым офицером, который находит и спасает ее среди блокадной действительности. Однако если у Чаковского «спасителем» выступает фронтовой офицер Звягинцев, то у Тургенева им становится гротескный и неоднозначный персонаж Максим, а НКВД - в соответствии с исторической реальностью - показан в романе как инстанция репрессивная и нравственно выродившаяся. Если у Чаковского ушедший на фронт жених - антипод Звягинцева, предатель, то у Тургенева предательство - также в соответствии с исторической реальностью - переосмыслено: жених Вари объявлен предателем за то, что якобъ сдался в плен. Таким образом, действительность, которая окружает героиню, стилизованную под комсомолку, верящую в советские идеалы, перестает быть «гладкой» и беспроблемной героической действительностью Чаковского - она невн ятна для Вари и одновременно легко понимаема постсоветским читателем, а главное, все менее может быть передана стилизованным под дискурс Чаковского внутренним языком героини, от которого остаются все более обрывочные фрагменты и который все больше становится языком переработанных Тургеневым свидетельств.

Второй элемент деконструкции «плоского мира» Чаковского - откровенная идеологическая пародия. В романе Тургенева, как и в «Блокаде», сюжетная линия партийной верхушки - также одна из основных, однако подвергается травестии, карнавализации и десакрализации - словно бы потому, что ее иначе нельзя изобразить, настолько эта реальность оторвана от блокадной жизни. Партаппаратчики здесь - не мудрая демиургическая сила, но циничные бала- 
ганные персонажи, а главной эмоцией изображается неизбывный еще более, чем голод у простых горожан, страх попасть в опалу («Сталин, приехав однажды в гости, остроумно пошутил: - А если бы ты, Маратик, покончил с собой, то в последней комнате могла быть твоя чучела. Самая большая!»; «А если бы ты, Маратик, покончил с собой шампуром в глаз, - так еще пошутил раздухарившийся после третьей бутылки вина Сталин, - то партия имела бы в активе чучелу Цыклопа!»; «Ощущение скорой пули не проходило уже ни на миг, не оставляло ни за работой, ни за едой. Или не пули: даже шкура медведя в родном кабинете на Петроградке таила, казалось, зубастую угрозу: воспрянет, ринется и перегрызет. У официантки в Смольном, что совсем уж нелепо, мог таиться под передником узкий кавказский кинжал. Основной версией оставалось, что заказал его Сталин, давно решил заполучить из Кирова главную чучелу страны, выставлять ее во все щели на Всероссийской выставке во всю мощь азиатского кремлевского коварства» ${ }^{26}$.

Третий - реальность, отсылающая к эпопее Чаковского, наполняется не свершившимися фактами героической гибели, а непрерывно тянущимся мотивом зависшей над городом смерти, мучительного умирания: «Городские люди внутри себя убывали в режиме как рыба вмерзает в лед, отличали себя от мертвых только в порядке инстинкта» ${ }^{27}$. Неслучайно маме Вари кажется, что они уже давно мертвы, причем это чувство описывается изнутри, как смерть-я: «...- Все обмирает внутри, доча, будто уже убили. Глаза закроешь, глаза раскроешь: живая! А потом еще другой летит и свистит. Сви-истит, позвоночник высасывает. И будто опять убил. И другой. Будто несколько раз в день убивают!»; «Варенькина мама говорила на кухне странное, будто их всех убило в начале войны одной невидимой бомбой, а что происходит - так это посмертные грезы и воспоминания мечт»; «- Я, Варвара, когда в кресле качаюсь, то так хорошо, все исчезает, а я будто одна остаюся и в пустоте качаюся, в пустоте. А потом смотрю: и сама уже исчезла. И меня не-етуу... Страшно, Варвара, страшно» ${ }^{28}$.

Однако город осмысляется как пространство смерти не только за счет реалий блокадной жизни. Миф блокадный (в который включена идея грядущего возрождения) накладывается на эсхатологический петербургский миф (о гибельности города и его грядущем неминуемом крахе), который обживает/переживает Максим, называющий себя «зрителем» или «пациентом Петербурга». Максим одержим чувством мести за утраченный во время строительства канала от Невы к Смольному палец: «Город-обезьяна должен быть уничтожен!»; «В общем и целом, о мести людям-ленинградцам Максим не помышлял. [...] Другое дело - месть городу, который проглотил, пережулькал, выплюнул и не поперхнулся. Холодный, расчисленный, бездушный, скептический [...] вреден этот город [...] Пока его грела хитрая, замысловатая причастность к делу унич-

26 Тургенев Андрей. Спать и верить: Блокадный роман.

27 Ibid.

28 Ibid. 
тожения Петербурга» ${ }^{29}$. В его видении (которое композиционно удерживает всю романную конструкцию) город страшен в своей антропоморфности и зооморфности, искусственен, искривлен, гнил, жесток, мертв.

Мистика, всегда сопутствовавшая «панхроническому» петербургскому тексту, превращается в пародийную реальность. Отсюда образ неожиданного соратника Максима глоссолала, представляющегося духом города, имеющим целью освободить наконец это уставшее от людей и принадлежащее нечистой силе пространство. Милиция всерьез гоняется по блокадному городу за привидением, в Доме ученых живет свой призрак и пр. На мистику Петербурга-Ленинграда накладывается известная, но также альтернативно домысленная история вскрытия-осквернения могилы Тамерлана, придавая размах картине влияния инфернальных сил.

Максим все больше видит не реальный город, а словно бы осуществление старого пророчества царицы о «пустом городе», и сам себя начинает ощущать орудием этого проклятия: «Повернулся, глянул через реку, а там пусто, только белая вата тумана, там уже нет ничего. Город сам исчезает, не дожидаясь, пока подтолкнут окончательно»; «ходил по комнате, рисовал в воображении диковинные картины. На Дворцовой, допустим, можно построить лабиринт. Такой, чтобы из группы запущенных посетителей один точно сгинул. Пожранный чудищем-монстром. Нет, чудища не надо, город будет пустой, туристы только на вертолетах. Ловушка. Разверзается булыжник в одном месте вдруг под тобой, и бздык»; «Мертвый город - вот декорация для „ледяных сущностей”»; «жалко-то как, какие декорации пропадают! Лучшие декорации в мире!»; «Похоже, прав Глоссолал Порфирьевич. Людей убрать, а город хороший. Как гулко будет выть ветер в пустых дворах-колодцах, метель свистеть по оставленным площадям! Бронзовое зеленеть, каменное трескаться, наводняющее - беспрепятственно наводнять. Духи - шелестеть и кружить, а вспугнутые ангелы - хлопать сверху большими глазами»; «Кого-то вывезти, другие умрут, немцы в марсов пуп всосутся, а пустой город - пусть» ${ }^{30}$.

Таким образом, Максим стремится не просто прочитать и дописать «петербургский текст» (его бред и провокации порой повторяют слова и действия героев Пушкина, Гоголя, Достоевского, Белого: «В нелепой декорации куковал Первый Петр, как раз и измысливший город-обезьяну. - Спрятался! - погрозил Максим Медленному. - Ужо горожане доски на печки растащат, задницу твою самодержавную оголят! Сколько душ при стройке положил, сколько? Тварей божьих сколько в болото зарыл, порфироносец? Божьих, а? Тварей?! [...] - Молчишь, истукан! Десятки тысяч положил мужичков, угробил во имя города-обезьяны! Вознесся их кровью, окно процарапал, доволен? Ужо! А мы в эту войну миллион тут уроем, два, три! Снилось тебе такое, призрачный царь? Да что тебе, истукан, вообще могло сниться...» ${ }^{31}$ и пр.), но инсценировать его

29 Ibid.

30 Ibid.

11231 Ibid. 
в грандиозных театральных декорациях замерзшего города: литературный образ-текст Петербурга перевоплощается в объемную театральную площадку, становясь из плоскостного трехмерным, насыщая образ Петербурга чертами современного перформанса.

Роман сталкивает явь и сон, документальную реальность и обрывки дискурсов, четкость и однозначность стилистики изображаемого времени с расплывчатостью современного сознания, веры сталинской эпохи - с неверием последующих, соединяет легенды блокадного времени со штампами шпионского романа и любовной мелодрамы, использует пародийные аллюзии на самые различные тексты (в том числе в военную реальность вводятся послевоенные тексты), от романов Сорокина до «Карлсона», «Волшебника Изумрудного города» или «Буратино», от А.Тарковского до В.Утки-Отки.

Откуда эта художественно-психологическая потребность авторов, обращающихся сегодня к столь болезненным темам, в использовании гротеска?

Представляется, что здесь есть параллель с иронично-парадоксальным провокационным методом, разработанный американским психотерапевтом Ф. Фарелли $^{32}$. Используемый, в частности, для лечения депрессии и нервно-психических перенапряжений, он направлен на формирование у клиента - при помощи преувеличения, передразнивания, высмеивания, искажения, сарказма, иронии, доведения до абсурда, черного юмора и пр. - комического сознания.

Комическое в свою очередь тесно связано с защитно-приспособительными возможностями личности и социума, может служить «механизмом безопасности, придающим человеку равновесие, перспективу и оптимальную психологическую дистанцию в его многообразной жизни» ${ }^{33}$. Ирония и сарказм, являясь эмоциональной трансформацией, жестким высмеиванием эмоциогенного события, поиском в нем абсурдного, нелепого, смешного, служат вербальной разрядке эмоций. Неслучайно лингвист Д. Хайман называет его наиболее приемлемым дискурсом современности ${ }^{34}$. Очевидные защитные функции имеет и черный юмор, направленный на те сферы человеческой жизни, которые, с точки зрения общепринятой морали, в той или иной степени табуированы для осмеяния. Отсылая к идеям Э. Фромма, В.И. Жельвис именует его «лучиком света, отразившимся от черноты адского зазеркалья», «хрупкой надеждой биофила [...], тем более слабой, что в попытке сохранить ее утопающий хватается за протянутую руку некрофила» ${ }^{35}$. Н.А. Масленкова проводит параллель между черным юмором и первобытным обрядом, видя их сходство именно в терапевтическом эффекте: его порождает «ситуация, в которую попадает смеющийся:

32 Подробнее см.: Адельгейм И.Е. Психология поэтики. Аутопсихотерапевтические функции художественного текста. Москва: Индрик, 2018. С. 508.

33 Фарелли Ф. Провокационная терапия. Екатеринбург: издательство «Екатеринбург», 1996. http://royallib.com/book/farrelli_frenk/provokatsionnaya_terapiya.html

34 Haiman J. Talk is Cheap: Sarcasm, Alienation, and the Evolution of Language. Oxford\&New York: Oxford University Press, 1998.

35 Жельвис В.И. «Черный юмор: анатомия человеческой деструктивности» www.yspu.yau.ru 
архаический смех, “носитель и даритель жизни”, является магическим средством преодоления смерти, преодоления страха и разрушения. Черный смех фактически делает то же самое, но не так, как это было в первобытном обряде. Маркируя границу между смертью (или угрозой смерти, жестокостью, страшным и пр.) и жизнью, подобный смех отделяет пространство смеющегося от изображаемого ${ }^{36}$. Значительным защитно-адаптивным потенциалом обладает и гротеск, способствующий эмоциональной разрядке, отстранению от обыденной реальности или отстранению от себя объекта и защите личных границ, карнавальному сопротивлению давлению извне и сохранению самооценки, а также высвобождению вытесненных переживаний и парадоксальной интеграции личности.

Именно такой, гротескный, отсылающий к масс-культуре сюжет, позволяющий жертвам Холокоста буквально и зримо постучаться в польскую дверь, заставляет молодого героя-повествователя Остаховича - имевшего прежде достаточно туманные представления о Холокосте обывателя - пройти своего рода «ускоренный курс» эмпатии и сострадания. Это словно бы иллюстрация к словам Д.Лакапры о том, что реакция на травматические события даже у свидетеля второй степени связана с эмпатическим беспокойством, которое оказывается «необходимым, аффективным измерением» исследования прошлого и «играет важную роль в попытках понять травматические события и жертв травмы» ${ }^{37}$.

«Запутанная польская память о евреях [...] по-прежнему нуждается в потрясении, - утверждает польская исследовательница Б. Пшимушала. - Нуждается порой даже и в триллере, чтобы увидеть собственную чудовищность» ${ }^{38}$. Созвучны ее мысли размышления актера А. Жмиевского: «Есть в Варшаве [...] памятник, на улице Ставки, там, где была Умшлагплац. Белый куб с написанными на двух языках - польском и иврите - именами; вокруг черная каменная полоса. Как-то я слушал радиопередачу об истории этого места. Журналистка опрашивала студентов экономического института, вплотную к зданию которого стоит памятник, знают ли они, где была Умшлагплац и где находится памятник жертвам Холокоста. Люди, дважды в день проходившие мимо этого места, не знали, где находится памятник, не знали, что такое Умшлагплац. Не знали, что в здании их института была еврейская больница на Умшлагплац. [...] Я подумал, что нам в Польше все-таки нужны другие памятники - не белые кубики, а наглядные истории с фигурами, как в комиксе. [...] әстетический императив мы не воспринимаем, а вот цветные комиксы - пожалуйста» 39.

36 Масленкова Н.А. (Не)культурный формат «черного юмора» // Санкт-Петербург: Центр изучения культуры, 20II. Studia Culturae, Выпуск г2. С. 147.

37 LaCapra D. Trauma, nieobecność, utrata // Antologia studiów nad traumą. Kraków: Universitas, 20I5. S. Ioo.

38 Przymuszała B. Smugi Zagłady. Emocjonalne i konwencjonalne aspekty tekstów ofiar i ich dzieci. Poznań: Wydawnictwo Naukowe UAM, 2016. S. I82.

39 Janicka E. Festung Warschau. Warszawa: Wydawnictwo Krytyki Politycznej, 20II. S. 90. 
Представляется, что визуализация ужаса памяти и беспамятства, национальных стереотипов необходима для его диссоциации, для того, чтобы ужас мог стать предметом анализа, а перспектива гротеска, деконструкция клише массовой культуры призвана действовать в качестве своего рода обезболивающего, «кавычек». Черный юмор в случае Хутник и карнавальное обыгрывание кодов масс-культуры у Остаховича способствуют, таким образом, помимо эмоциональной разрядки в ситуации вытесненного чувства вины и порожденного им страха, психологической интеграции - содействуют «трансформации ранее отчужденных аспектов “я” в полноправные аспекты целостной личности, “избегая при этом откровенной идентификации с ними” ${ }^{40}$.

Подобно тому, как у Остаховича и Хутник, чтобы пережить непережитое траур по уничтоженным и подвергшимся забвению еврейским соседям - необходимо сперва «оживить» их, дать право голоса и действия, «реализовать» в тексте и пугающее своей вечной нереализованностью возмездие, и возможность исправить ошибки предков, повести себя принципиально иначе, защитить у Тургенева, чтобы преодолеть не охватывающий весь массив травматического опыта одноплановый победный нарратив, его нужно «оживить», опробовать самому, убедиться в его неадекватности. Ни то, ни другое невозможно в чисто реалистической парадигме.

Чудовищность, но и абсурдность поведения власти в блокадном городе, являющаяся реальным (уже обжитым сознанием современного читателя) историческим слоем, словно бы «придавливается» введением уже откровенного абсурда, элементов фантасмагории, но, в сущности, с точки зрения человеческой морали и нормальной логики, они ничем не отличаются (однако на фоне наращивания бреда первый остраняется как условно «нормальный»). Так, например, якобы арестованному по заведомо ложному обвинению директору Әрмитажа, затем выпущенному для того, чтобы зарыть обратно Тамерлана с его проклятием, предлагают в качестве особого одолжения лечь к тому в могилу: Щросто есть такая возможность. В виде признания заслуг и особой чести. Мне поручено вам о том сообщить. - А... Я не влезу. Саркофаг на одного предназначен. - Сверху. На Тимура. Попрать супостата» ${ }^{41}$ и директор всерьез задумывается и азартно соглашается. Кроме того, если единственная реальная точка соприкосновения двух пластов жизни - блокадников и партийной верхушки - это репрессии, то единственное человеческое/человечное звено, соединяющее их, - может быть только гротескным. Гротескные эпизоды, направленные на табуированные объекты национального дискурса, погружают авторов в особую инвективную

40 Jakab I. Humor and psychoanalysis // L'Humor. Histoire, culture et psychologie. Paris: Publications de la Société internationale de psychothérapie de l'expression et d'art-thérapie, 1998. Р. 17-18. Цит. по: Копытин А.И. Юмор в искусстве и арт-терапии: феноменология, диагностика, защитно-адаптивные возможности. // Медицинская психология в России, 20I2, №4 (Is) URL: http:/ medpsy.ru/mprj/archiv_global/20I2_4_I5/nomer/nomero2.php Дата обращения: ог.02.202I.

41 Тургенев Андрей. Спать и верить: Блокадный роман. 
атмосферу ${ }^{42}$ : как в любой карнавальной ситуации, табу взламывается, а психологический аспект этого феномена заключается в желании говорящего достичь сразу двух противоположных целей - избежать соприкосновения с табуированными понятиями и одновременно этого соприкосновения добиться. Таким образом, достигается своего рода катартический выход эмоций.

Роман таким образом оказывается «весьма сильной по воздействию на читателя попыткой создания нетоталитарного текста» ${ }^{43}$. Название «Спать и верить» отсылает, очевидно, к цитате из «Блокады» Чаковского - «молчать и слушать». В этом «спать и верить» одновременно - блокада как событие и блокада как нарратив. Физиология блокадного жителя, частная и официальная его идеология, предательство по отношению к нему со стороны власти (остается только спать и верить, что дождешься), спящая вера в рождение и разрешение сверху и снизу на бытование адекватного чудовищному опыту языка.

Рассматривая литературу как одну из инстанций конструирования травмы, Д. Александер говорит, что ее роль в этом процессе - подготовка отождествления с жертвой. В случае с новой литературой о блокаде и Холокосте такая подготовка невозможна «без существенной трансформации субъективных структур и изобразительных стратегий, без «прорыва к опыту» ${ }^{44}$. По замечанию Урицкого, смысловые пласты романа «Спать и верить», «сталкиваясь, порождают дикую какофонию, сопровождаемую шумом стилистических экспериментов, но на выходе дающую, как ни странно, ощущение художественной и человеческой значимости, парадоксально соединенное с тревожащей внутренней пустотой» ${ }^{45}$.

\section{Bibliografia}

Adel'gejm I.E., 2008, Psikhologiya poebtiki. Autopsikhoterapevticheskie funkcii khudozhestvennogo teksta. Moskva: Indrik.

Assman A. 2014, Dlinnaya ten'proshlogo. Memorial'naya kul'tura i istoricheskaya polityka, NLO, Moskva.

Assmann A., 2013, Między historia a pamięcią. Antologia, Wydawnictwo Uniwersytetu Warszawskiego, Warszawa.

Bauman Z. 1995, Wieloznaczność nowoczesna, nowoczesność wieloznaczna, Wydawnictwo Naukowe PWN, Warszawa.

42 Жельвис В.И. Некоторые эмоциогенные особенности инвективного общения // Язык и эмоции: сборник научных трудов. Волгоград: Перемена, 1995. С. 30.

43 Гликман К.В. Рецензия на «Спать и верить» А.Тургенева // Вопросы литературы. 2009. Май-июнь. С. ІІ7-ІІ8.

44 Воробьева (Вежлян) Е. Прорвать заграждение: блокада Ленинграда как символ и опыт.

45 Урицкий А. Такая странная (страшная?) игра ... [Рецензия на книгу : Тургенев А. Спать и верить: Блокадный роман. М., 2007] // Новое литературное обозрение. 2008. № 3. С. 340. 
Bauman Z., 2007, Świat nawiedzony, „Więź”, nr 9.

Bogdanova O. «Spat' i verit'» Andreya Turgeneva, ili «Blokadnyj roman» Vyacheslava Kuricyna. URL: https://zvezdaspb.ru/index.php?page $=8 \&$ nput $=$ IO $3 \mathrm{I}$

Chutnik S., 2014, W krainie czarów, Znak, Kraków.

Farelli F., 1996, Provokacionnaya terapiya, Izdatelstvo „Ekaterinburg”, Ekaterinburg. URL:http://royallib.com/book/farrelli_frenk/provokatsionnaya_terapiya.html

Ginzburg L., 20I4, Zapiski blokadnogo cheloveka. Izbrannaya proza, Lenizdat, Sankt-Peterburg. Glikman K.V., 2009, Recenziya na «Spat'iverit'» A. Turgeneva, „Voprosy literatury”, Maj-iyun’. Haiman J., 1998, Talk is Cheap: Sarcasm, Alienation, and the Evolution of Language, Oxford University Press, Oxford \& New York.

Hoberman J., 2009, Quentin Tarantino's Inglourious Basterds Makes Holocaust Revisionism Fun, "Village Voice", August i8. URL: www.villagevoice.com/film/quentin-tarantinos-inglourious-basterds-makes-holocaust-revisionism -fun-6391999

Jakab I., 1998, Humor and psychoanalysis, [w:] L'Humor. Histoire, culture et psychologie, Publications de la Société internationale de psychothérapie de l'expression et d'art-thérapie, Paris, s. 17-I8, cyt. za: Копытин А.И., Юмор в искусстве и арт-терапии: феноменология, диагностика, защитно-адаптивные возможности, 2ol2, [w:] Moskva: Медицинская психология в России” nr 4 (Is) URL: http:/medpsy.ru/mprj/archiv_global/2012_4_I5/nomer/nomero2.php

Janicka E., 2oII, Festung Warschau, Wydawnictwo Krytyki Politycznej, Warszawa.

LaCapra D., 2009, Historia wokresie przejściowym. Doświadczenie, tożsamość, teoria krytyczna, Universitas Kraków.

LaCapra D., 2015, Trauma, nieobecnosć, utrata // Antologia studiów nad trauma, Universitas Kraków.

Maslenkova N.A., 20oI, (Ne)kul'turnyj format «chernogo yumora», Tsentr izucheniya kul'tury, Sankt-Peterburg, Studia Culturae, wypusk i2.

Ostachowicz I., 20I2, Noc żywych Żydów, WAB, Warszawa.

Przymuszała B., 2016, Smugi Zagłady. Emocjonalne $i$ konwencjonalne aspekty tekstów ofiar $i$ ich dzieci Wydawnictwo Naukowe UAM, Poznań, 2016.

Sendyka R. Pryzma, 2013, Zrozumieć nie-miejsce pamięci, „Teksty Drugie”, nr I/2.

Szczepan A., 20II, Polski dyskurs posttraumatyczny. Literatura polska ostatnich lat wobec Holokaustu i tożsamości żydowskiej, [w:] Kultura po przejściach, osoby z przesztościa. Polski dyskurs postzależnościowy. Konteksty i perspektywy badawcze, Universitas, Kraków.

Tokarska-Bakir J. 2004, Historia jako fetysz, [w:] Tokarska-Bakir J., Rzeczy mgliste, Pogranicze, Sejny. 
Turgenev A. 2007, Spat' i verit': blokadnyj roman, EKSMO, Moskva. URL: https://royallib. com/read/turgenev_andrey/spat_i_veritblokadniy_roman.html\#o

Urickij A., 2009, Takaya strannaya (strashnaya?) igra ... [Recenziya na knigu: Turgenev A. Spat' i verit': blokadnyj roman. M., 2007], „Novoye literaturnoye obozreniye”, nr 3.

Vorob'eva (Vezhlyan) E., 20I6, Prorvat' zagrazhdenie: blokada Leningrada kak simvol i opyt, „Novoye literaturnoye obozreniye”, nr I URL: https://www.nlobooks.ru/magazines/novoe_ literaturnoe_obozrenie/I37_nlo_I_20I6/article/II8oI/

Zhel'vis V.I., «Chernyj yumor: anatomiya chelovecheskoj destruktivnosti». URL: www.yspu. yau.ru

Zhel'vis V.I., I995, Nekotorye emotsiogennyye osobennosti invektivnogo obshcheniya, [w:] Yazyk iemotsii: sbornik nauchnykh trudov, Peremena, Volgograd.

\section{STRESZCZENIE}

„Co diabet robi na naszej kanapie?”. Holokaust i Blokada Leningradu w prozie Sylwii Chutnik, Igora Ostachowicza, Andrieja Turgieniewa

W artykule zaanalizowano teksty polskich autorów Igora Ostachowicza i Sylwii Chutnik oraz rosyjskiego pisarza Andrieja Turgieniewa (pseudonim Wiaczesława Kuricyna), zrodzone perspektywę postpamięci, wcześniej czy później odsłaniającej i wypełniającej „białe plamy” - przez poczucie, że adekwatny dyskurs nie został wypracowany lub też istniejący już dyskurs nie funkcjonuje. Teksty literackie odnoszą się do tej części traumy historycznej, która nie została dostatecznie przepracowana albo została wyparta ze względu na haniebny lub przynajmniej nieheroiczny charakter doświadczenia, co uniemożliwia włączenie go do wielkiej narracji. Głównym pytaniem, na które stara się odpowiedzieć autorka artykułu, jest psychologiczno-artystyczny powód posługiwania się groteską, sarkazmem, czarnym humorem w odniesieniu do tematów sakralizowanych przez samą skalę ludzkiej tragedii - doświadczenie Holokaustu i oblężenie Leningradu.

\section{SŁOWA KLUCZOWE}

Holokaust, oblężenie Leningradu, postpamięć, wielka narracja, trauma historyczna, Warszawa, Muranów, groteska, dekonstrukcja, terapia prowokatywna Franka Farrelliego

\section{ABSTRACT}

"What is the Devil Doing on our Sofa?": The Holocaust and the Leningrad Blockade in the Prose of Sylvia Chutnik, Igor Ostachowicz, Andrei Turgenev

The article analyzes the texts of the Polish authors Igor Ostachowicz and Sylvia Chutnik and the Russian writer Andrei Turgenev (the pen name of Vyacheslav Kuritsyn), generated by 
«Что делает двявол на намем диване?»: холокост и Ленинградская блокада в прозе Сильвии Хутник...

post-memory perspective, sooner or later revealing and filling the «blank spots», through the feeling that an adequate discourse has not been worked out or the existing discourse «doesn't work». The literary texts refer to the part of historical trauma that was not (at all or sufficiently) worked through, was repressed because of its shameful or, at least, non-heroic nature, which prevents the inclusion of this experience into the «big narrative». The main question that the author of the article is trying to answer concerns the psychological and artistic reasons for using grotesque, sarcasm, and black humor when referring to topics sacralized by the very scale of human tragedy - the experience of the Holocaust and the Siege of Leningrad.

\section{KEY WORDS}

Holocaust, the Siege of Leningrad, post-memory, big narrative, historical trauma, Warsaw, Muranów, grotesque, deconstruction, provocative therapy of F. Farrelli 